\title{
Benign CD10-Positive T Cells in Reactive Lymphoid Proliferations and B-Cell Lymphomas
}

James R. Cook, M.D., Ph.D., Fiona E. Craig, M.D., Steven H. Swerdlow, M.D. Department of Pathology, University of Pittsburgh School of Medicine, Pittsburgh, Pennsylvania

Recent reports have indicated that the neoplastic $T$ cells of angioimmunoblastic T-cell lymphoma express CD10. It has been suggested that the demonstration of a CD10+ T-cell population may assist in establishing a diagnosis of angioimmunoblastic T-cell lymphoma and in distinguishing angioimmunoblastic T-cell lymphoma from other peripheral T-cell lymphomas. It has been unclear, however, whether this phenotypically unusual T-cell population might be present in other settings as well. In this report, we have retrospectively examined 64 cases of lymph node and solid tissue biopsies for the presence of $\mathrm{CD10}+\mathrm{T}$ cells using multicolor flow cytometry. Discrete populations of $\mathrm{CD10}+\mathrm{T}$ cells were found in 5 of 28 cases (18\%) of reactive lymphoid hyperplasia, 4 of 17 cases (23\%) of follicular lymphoma, and 9 of 19 cases $(47 \%)$ of marginal zone B-cell lymphomas. The $\mathrm{CD} 10+\mathrm{T}$ cells constituted $1-6 \%$ of total cells analyzed and $\leq 14 \%$ of the total T-cell population. Using two-color immunohistochemical stains, many of the CD10+ PAX5negative presumptive $T$ cells were found to be located within germinal centers. These findings indicate that a normal small subset of CD10+ peripheral $\mathrm{T}$ cells exists and, at least when present in small numbers, should not be considered an indication of a T-cell neoplasm.

KEY WORDS: CD10, Germinal centers, T-cell phenotype.

Mod Pathol 2003;16(9):879-885

The expression of CD10 by lymphoid cells correlates with specific stages of development and maturation $(1,2)$. Lymphoblasts, of both B- and T-cell lineages, demonstrate expression of $\mathrm{CD} 10$ that is

Copyright (C) 2003 by The United States and Canadian Academy of Pathology, Inc

VOL. 16, NO. 9, P. 879, 2003 Printed in the U.S.A.

Date of acceptance: June 4, 2003.

Address reprint requests to: Steven H. Swerdlow, M.D., Division of Hematopathology, Room C606-PUH, Department of Pathology, University of Pittsburgh School of Medicine, Pittsburgh, PA 15213; fax: 412-647-4008; e-mail: swerdlowsh@upmc.edu.

DOI: $10.1097 / 01 . M P .0000084630 .64243 . D 1$ lost upon progression to a mature phenotype. Mature B cells express CD10 again during the germinal center reaction, with subsequent loss of expression as the B cells leave the germinal centers as memory B cells and/or plasma cells $(1,3)$. The expression of CD10 by mature T cells, however, has not been well characterized.

Angioimmunoblastic T-cell lymphoma is a rare malignant neoplasm of mature $\mathrm{T}$ cells associated with a spectrum of morphologic features that in some cases may overlap with the findings in abnormal reactive proliferations $(4,5)$. Definitive diagnosis often can be difficult without evidence of clonality as demonstrated by either genotypic or cytogenetic studies. There is therefore great interest in identifying potential immunophenotypic findings that could aid in the identification of angioimmunoblastic T-cell lymphoma. Recent reports have indicated that the neoplastic $\mathrm{T}$ cells in angioimmunoblastic T-cell lymphoma express CD10 and have suggested that the demonstration of a CD10 $0^{+} \mathrm{T}$-cell population may aid in the diagnosis of this specific type of T-cell lymphoma (6-8). However, it has been unclear whether $\mathrm{CD}^{+}{ }^{+}$mature $\mathrm{T}$ cells may also be present in other lymphoid proliferations as well and whether CD10 expression by mature $\mathrm{T}$ cells represents a normal T-cell subset or an aberrant phenotype.

In this study, we analyzed flow cytometry data and histograms from 64 cases of lymph node or solid tissue biopsies containing reactive lymphoid hyperplasia, follicular lymphoma, or marginal zone B-cell lymphoma. The percentage and distribution of $\mathrm{CD}^{+} / \mathrm{CD} 0^{+} / \mathrm{CD} 9^{-}$cells was evaluated, and the $\mathrm{T}$-cell origin of these cells was directly confirmed in four cases using analysis of CD10 and CD3 coexpression. Selected cases were also examined by dual-color immunohistochemical stains using CD10 and the PAX5 nuclear B-cell marker to identify the anatomic location of the $\mathrm{CD} 10^{+} \mathrm{PAX}^{-}$presumptive $\mathrm{T}$ cells.

\section{MATERIALS AND METHODS}

\section{Case Selection}

Cases selected for retrospective analysis included 28 cases of reactive lymphoid hyperplasia, 17 cases 
of follicular lymphoma, and 19 cases of marginal zone lymphoma. The cases of reactive lymphoid hyperplasia and follicular lymphoma represent cases with diagnostic flow cytometry over a 6-month period at UPMC-Presbyterian and were described in a previous study (9). The cases of marginal zone lymphoma represent all cases of marginal zone lymphoma with diagnostic flow cytometric immunophenotypic studies performed at UPMC-Presbyterian over a 1-year period. In addition, four cases of lymph node biopsies containing $\mathrm{CD}_{10}{ }^{+} \mathrm{T}$ cells (3 follicular lymphomas, 1 marginal zone lymphoma) were identified in a prospective fashion during routine practice. Cases of follicular lymphoma and marginal zone lymphoma were chosen for study in part because $\mathrm{CD}^{+}{ }^{+} \mathrm{T}$ cells were first noted in such cases by flow cytometric analyses in our routine practice. Furthermore, these cases often contain follicular structures, and the malignant $\mathrm{CD} 0^{+} \mathrm{T}$ cells of angioimmunoblastic T-cell lymphoma are thought to have a relationship to abnormal follicular structures (6-8). All diagnoses were rendered according to WHO criteria using histologic, immunohistochemical, and/or flow cytometric findings (10).

\section{Flow Cytometry}

Flow cytometric analysis was performed as previously described (11). The presence of $\mathrm{CD} 10^{+}$ $\mathrm{T}$-cell populations was evaluated via three-color analysis using CD5-FITC (Clone L17F12, Becton Dickinson, Franklin Lakes, NJ), CD10-PE (Clone SS2/36, DAKO, Carpinteria, CA), and CD19-PC5 (Clone J4.119, Beckman Coulter, Fullerton, CA). Data were acquired on 10,000 cells per sample using a Becton Dickinson FACScalibur with CellQuest software (Becton Dickinson). Data were analyzed using CellQuest and Paint-a-Gate software (Becton Dickinson). $\mathrm{CD}^{+} 0^{+} \mathrm{T}$ cells were identified and quantified by gating first on CD10-positive events with subsequent gating on $\mathrm{CD}^{+} \mathrm{CD}^{-} 9^{-}$events. In the prospectively identified cases, the cell suspensions were also analyzed in similar fashion after staining with one of the following antibody combinations: CD10-PE/CD3-FITC (Clone SK7, Becton Dickinson), CD10-PE/CD3-FITC/CD19-PC5, CD10PE/CD3-PerCP (Clone SK7, Becton Dickinson), or CD10-PE/CD3-PerCP/CD57-FITC (Clone HNK-1, Becton Dickinson).

\section{Immunohistochemistry}

Two-color immunohistochemical stains were performed on formalin-fixed, paraffin-embedded tissues as previously described (12). Briefly, slides were deparaffinized, pretreated by microwaving in citrate buffer (10 mu citrate, $\mathrm{pH}$ 6.0), and manually stained using the Vectastain Elite ABC kit (Vector Laboratories, Burlingame, CA). Slides were stained first with CD10 (DAKO, Carpinteria, CA; 1:10 dilution) and nickel 3,3'-diaminobenzidine chromogen (Vector Laboratories), followed by PAX5 (Transduction Laboratories, Lexington, KY; 1:50 dilution) and Vector Red chromogen (Vector Laboratories). No counterstain was employed.

\section{Statistical Analyses}

Statistical analyses were performed as indicated using GraphPad Prism software (GraphPad Software, San Diego, CA).

\section{RESULTS}

Routine flow cytometric histograms of lymph node or solid tissue biopsies containing reactive lymphoid hyperplasia, follicular lymphoma, or marginal zone lymphoma were retrospectively reviewed for the presence of $\mathrm{CD} 10^{+} \mathrm{T}$ cells, identified as cells with a $\mathrm{CD} 5^{+} \mathrm{CD} 10^{+} \mathrm{CD} 19^{-}$phenotype (Fig. 1). Discrete populations of $\mathrm{CD} 0^{+} \mathrm{T}$ cells were identified in 5 of 28 cases of reactive lymphoid hyperplasia (18\%), 4 of 17 cases of follicular lymphoma (23\%), and 9 of 19 cases of marginal zone lymphoma (47\%; Table 1). The cases classified as lacking discrete populations of $\mathrm{CD}^{+} 0^{+} \mathrm{T}$ cells displayed few, scattered events in the $\mathrm{CD}^{+} \mathrm{CD} 10^{+} \mathrm{CD} 19^{-}$region that did not form distinct populations in flow cytometric dot plots and represented $\leq 2 \%$ of total events analyzed. The viability of the specimens at the time of analysis in cases with $(92 \pm 5 \%)$ and without $(84 \pm 18 \%)$ discrete $\mathrm{CD}^{+} 0^{+} \mathrm{T}$-cell populations were similar $(P=.07$, unpaired Student's $t$ test).

The $\mathrm{CD}^{+} 0^{+} \mathrm{T}$ cells consistently demonstrated strong expression of CD5, similar to that of other T cells, and tended to show limited variability in forward- and side-scatter characteristics (Fig. 1). The proportion of $\mathrm{CD}^{+} 0^{+} \mathrm{T}$ cells ranged from 1 to $6 \%$ of total events analyzed, and accounted for $\leq 14.4 \%$ of all $\mathrm{T}$ cells present in the specimen. In cases of marginal zone lymphoma, the $\mathrm{CD}_{10} 0^{+} \mathrm{T}$ cells represented a larger proportion of the $\mathrm{CD} 10^{+}$ lymphoid population $\left(\leq 75.5 \%\right.$ of $\mathrm{CD}^{+} 0^{+}$cells) than in reactive lymphoid hyperplasia or follicular lymphoma.

In addition to the retrospective analysis, four B-cell lymphomas containing $\mathrm{CD}^{+} 0^{+} \mathrm{T}$ cells with sufficient material for further flow cytometric studies were identified in a prospective fashion (three follicular lymphomas and one marginal zone lymphoma). In each of these cases, definitive coexpression of CD3 and CD10 was identified (Fig. 2). Similar percentages of $\mathrm{CD} 0^{+} \mathrm{T}$ cells were enumerated whether identified as $\mathrm{CD}^{+} \mathrm{CD}^{+} 0^{+}$cells or as 

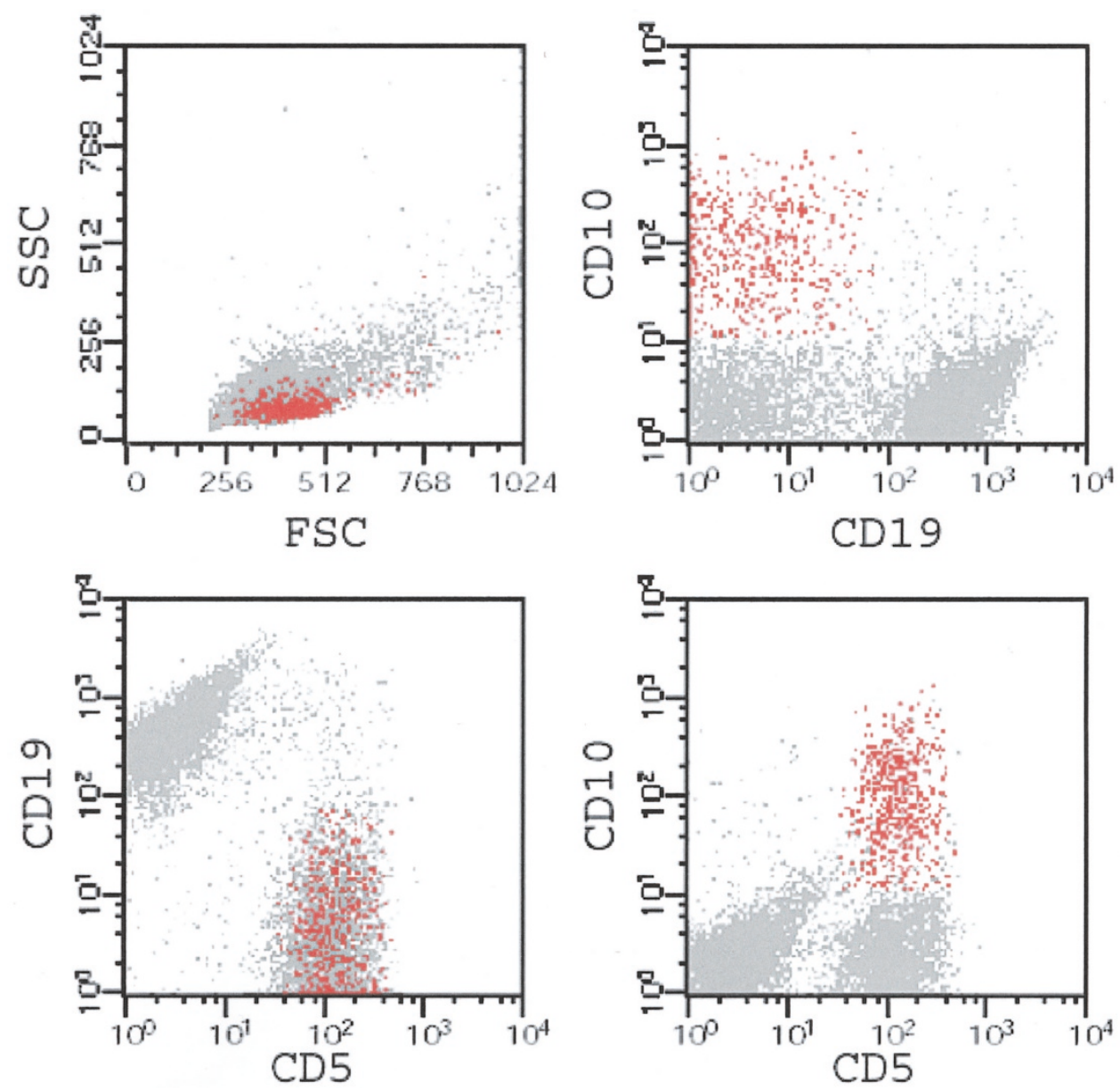

FIGURE 1. CD10+ $\mathrm{T}$ cells in a case of marginal zone lymphoma. CD10 $0^{+} \mathrm{T}$ cells (red) demonstrated strong expression of CD5, varying intensities of $\mathrm{CD} 10$, and relatively uniform forward and side scatter.

TABLE 1. Retrospective Analysis of Lymph Node and Solid Tissue Biopsies Containing CD10+ T-Cell Populations

\begin{tabular}{|c|c|c|c|c|c|c|}
\hline Diagnosis & $\begin{array}{l}\text { CD19+ Cells } \\
\text { (\% total cells) }\end{array}$ & $\begin{array}{l}\text { CD10+ Cells } \\
\text { (\% total cells) }\end{array}$ & $\begin{array}{l}\text { CD5+ Cells } \\
\text { (\% total cells) }\end{array}$ & $\begin{array}{l}\text { CD10+ T-Cells } \\
\text { (\% total cells) }\end{array}$ & $\begin{array}{l}\text { CD10+ T-Cells/ } \\
\text { All T-Cells (\%) }\end{array}$ & $\begin{array}{c}\text { CD10+ T-Cells/ } \\
\text { All CD10 Cells } \\
\text { (\%) }\end{array}$ \\
\hline RLH & 26 & 11 & 75 & 5.5 & 7.4 & 50.4 \\
\hline RLH & 29 & 6 & 69 & 2.3 & 3.3 & 37.8 \\
\hline RLH & 42 & 19 & 57 & 2.1 & 3.7 & 11.0 \\
\hline RLH & 51 & 14 & 52 & 2 & 3.8 & 14.3 \\
\hline RLH & 54 & 34 & 48 & 2.4 & 5.1 & 7.2 \\
\hline FL & 69 & 53 & 32 & 2.5 & 7.9 & 4.8 \\
\hline FL & 60 & 62 & 41 & 3.3 & 7.9 & 5.2 \\
\hline $\mathrm{FL}$ & 68 & 66 & 33 & 1.8 & 5.3 & 2.7 \\
\hline $\mathrm{FL}$ & 50 & 46 & 50 & 2.0 & 3.9 & 4.3 \\
\hline MZL & 60 & 16 & 42 & 3.8 & 8.9 & 23.5 \\
\hline MZL & 50 & 9 & 54 & 3.7 & 6.8 & 41.0 \\
\hline MZL & 84 & 4 & 18 & 1.4 & 7.9 & 35.5 \\
\hline MZL & 78 & 5 & 24 & 1.0 & 4.2 & 20.0 \\
\hline MZL & 58 & 4 & 41 & 2.6 & 6.4 & 65.5 \\
\hline MZL & 62 & 8 & 42 & 6.0 & 14.4 & 75.5 \\
\hline MZL & 80 & 5 & 19 & 1.6 & 8.3 & 31.6 \\
\hline MZL & 77 & 41 & 25 & 1.9 & 7.4 & 4.5 \\
\hline MZL & 88 & 3 & 13 & 1.4 & 10.5 & 45.7 \\
\hline
\end{tabular}

$\mathrm{RLH}=$ reactive lymphoid hyperplasia; FL = follicular lymphoma; MZL = marginal zone lymphoma.

$\mathrm{CD}^{+} \mathrm{CD} 10^{+} \mathrm{CD} 19^{-}$cells (Table 2), indicating that at least the vast majority of $\mathrm{CD}^{+} 0^{+} \mathrm{T}$ cells also express CD3 and that either antibody combination provides an accurate determination of the number of $\mathrm{CD}_{10} 0^{+} \mathrm{T}$ cells present. The intensity of $\mathrm{CD} 3$ expression tended to be slightly lower in the $\mathrm{CD} 10^{+}$ 

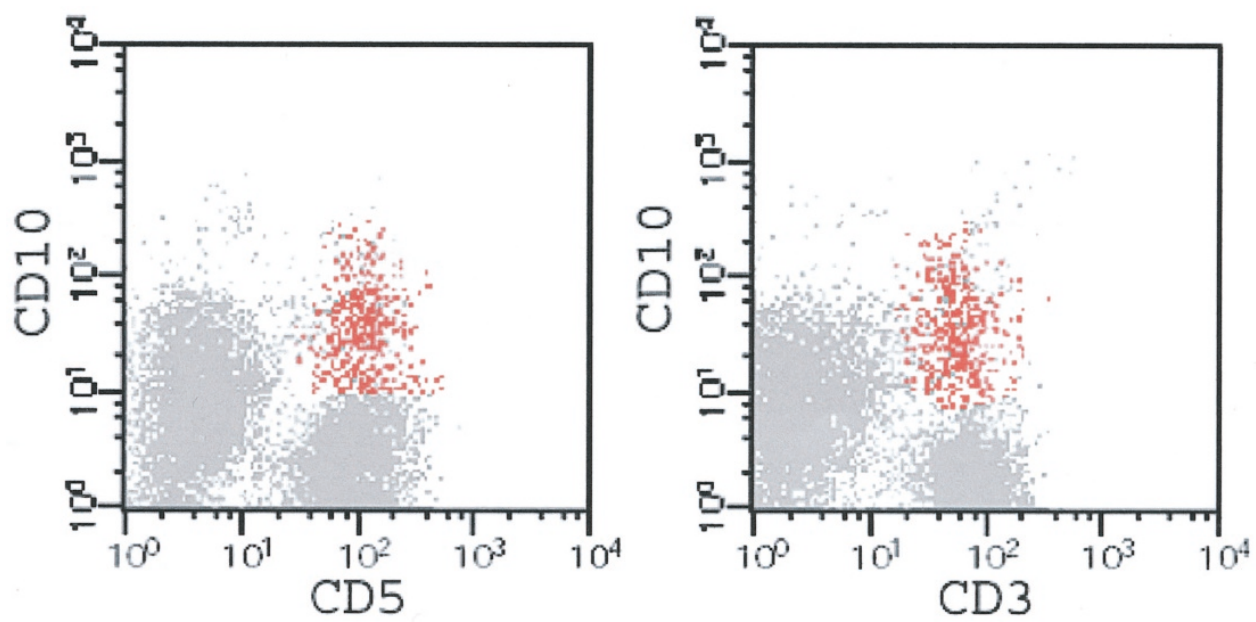

FIGURE 2. $\mathrm{CD} 3$ expression in $\mathrm{CD}_{10}{ }^{+} \mathrm{T}$ cells. Similar percentages of $\mathrm{CD} 10^{+} \mathrm{T}$ cells are identified by counting either $\mathrm{CD} 5^{+} \mathrm{CD} 10^{+} \mathrm{CD} 19^{-}$cells $($left $)$ or $\mathrm{CD}^{+} \mathrm{CD}_{10}{ }^{+}$cells (right). Note the weaker CD3 expression in the CD10 ${ }^{+}$compared with the CD10 ${ }^{-} \mathrm{T}$ cells.
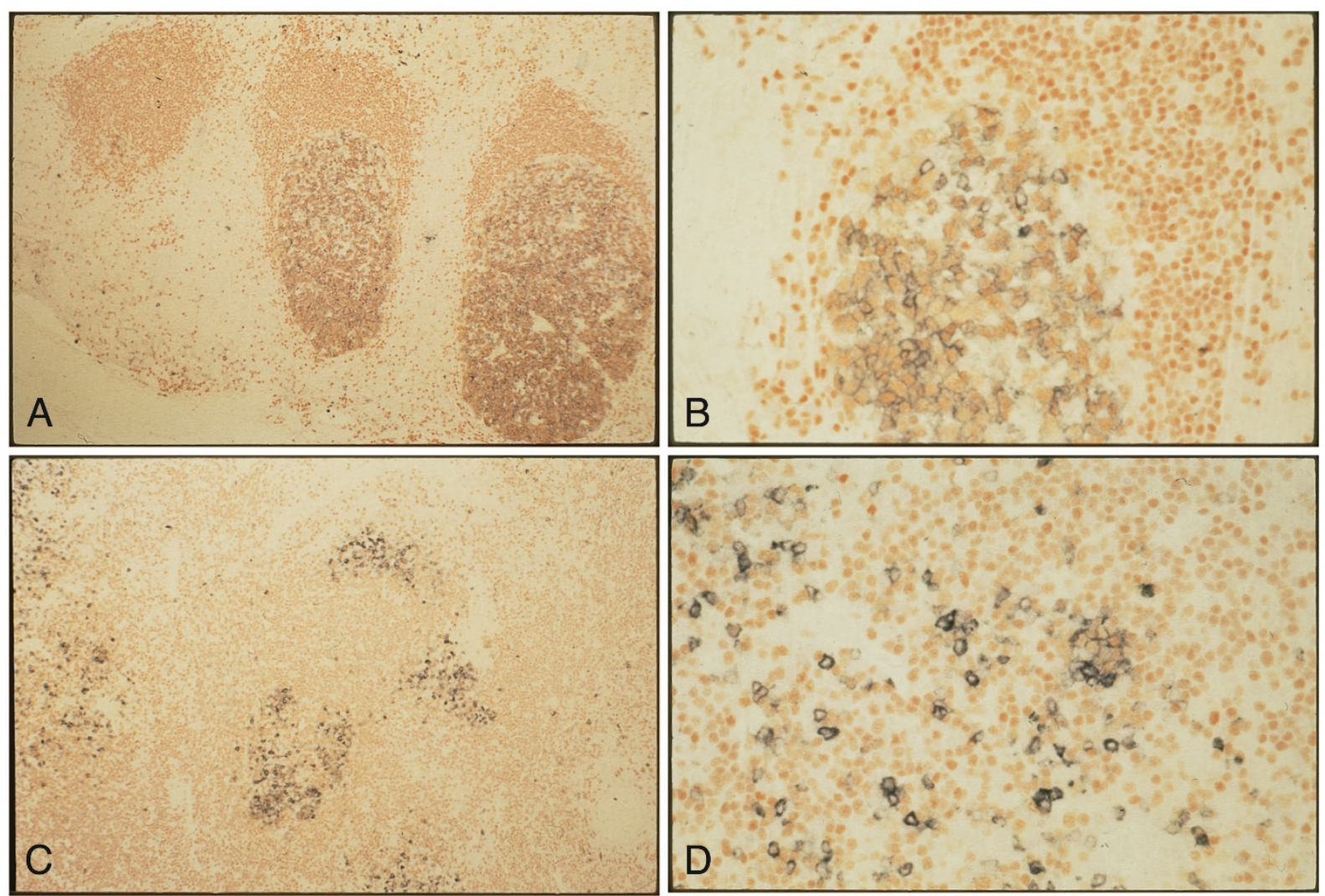

FIGURE 3. Anatomic localization of $\mathrm{CD} 10^{+}$presumptive T cells. Two-color immunohistochemical stains for CD10 (black) and PAX5 (red) demonstrate $\mathrm{CD}_{10}{ }^{+} \mathrm{PAX}^{-}$cells primarily within germinal centers in benign control tonsils (A, B). A case of marginal zone B-cell lymphoma contains

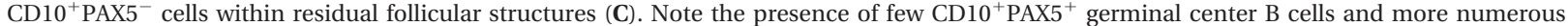
$\mathrm{CD}{ }^{+} \mathrm{PAX}^{-} \mathrm{T}$ cells at higher magnification (D). Magnification: $100 \times(\mathbf{A}, \mathbf{C})$ and $400 \times(\mathbf{B}, \mathbf{D})$.

T cells $(32.1 \pm 5.9, \mathrm{MFI} \pm \mathrm{SEM})$ than in the CD10 $\mathrm{T}$ cells $(41.4 \pm 8.1$, MFI $\pm \mathrm{SEM})$, although this difference was not statistically significant $(P=.138$, paired $t$ test). In the one case in which CD57 expression was analyzed, the majority of $\mathrm{CD} 10^{+} \mathrm{T}$ cells lacked CD57 expression (data not shown).

To identify the anatomic location of the $\mathrm{CD}^{+} 0^{+} \mathrm{T}$ cells, two-color immunohistochemical stains were performed using antibodies against CD10 and the nuclear pan-B-cell marker, PAX5, on all cases with $>2 \% \mathrm{CD} 0^{+} \mathrm{T}$ cells and available paraffin blocks (two reactive lymphoid hyperplasias, two follicular lymphomas, and four marginal zone lymphomas). Sections of benign tonsils were also stained in similar fashion. Interpretation of these stains was complicated as the somewhat diffuse-appearing CD10 
TABLE 2. CD10+ T-Cells Identified as Either CD5+CD10+ Cells or CD3 +CD10 + Cells in Prospectively Identified Cases

\begin{tabular}{ccc}
\hline Diagnosis & $\begin{array}{c}\text { CD5 }+ \text { CD10+ } \\
\text { (\% total cells) }\end{array}$ & $\begin{array}{c}\text { CD3+ CD10+ } \\
\text { (\% total cells) }\end{array}$ \\
\hline FL & 2.2 & 2.5 \\
FL & 4.6 & 4.7 \\
FL & 8.3 & 9.4 \\
MZL & 1.8 & 1.3 \\
\hline
\end{tabular}

staining of germinal center B cells frequently appeared to be partially masked by PAX5 staining that often gave increased cytoplasmic background staining in germinal centers. However, the stains did clearly identify PAX5-negative lymphoid cells with strong membrane positivity for CD10, consistent with $\mathrm{CD} 10^{+} \mathrm{T}$ cells. In cases of reactive lymphoid hyperplasia and in benign control tonsillar tissues, the $\mathrm{CD} 10^{+} \mathrm{T}$ cells appeared to be distributed as single cells within follicles and occasionally in mantle zones, with rare scattered cells in the interfollicular areas (Fig. 3, A-B). Marginal zone lymphoma cases with residual germinal centers also contained $\mathrm{CD} 10^{+} \mathrm{T}$ cells primarily within follicular structures (Fig. 3, C-D). In two marginal zone lymphoma cases, residual germinal centers were not present in the sections analyzed, and $\mathrm{CD} 0^{+} \mathrm{PAX} 5^{-}$cells were present scattered throughout the lymphomatous infiltrate. Two-color immunostains performed on cases of FL could not be satisfactorily interpreted because of the density of $\mathrm{CD}{ }^{+} / \mathrm{PAX}^{+}$cells present.

\section{DISCUSSION}

The CD10 antigen is a $100-\mathrm{kDa}$ cell surface protein with endopeptidase activity $(1,2)$ that, although originally described as a potential leukemia-specific antigen (13), is now known to be expressed by a variety of hematopoietic, epithelial, and mesenchymal tissues (14-17). Among hematopoietic cells, CD10 expression is found in granulocytes and in $\mathrm{B}$ and $\mathrm{T}$ lymphocytes at particular stages of maturation. CD10 expression within the $\mathrm{B}$-cell lineage has been very well characterized. Benign CD10+ B cells include B lymphoblasts as well as mature germinal center B cells $(1,18)$. CD10 is also characteristically expressed by several B-cell malignancies, including a subset of lymphoblastic lymphomas and leukemias, and mature B-cell lymphomas of follicular center cell origin including follicular lymphomas and a subset of diffuse large B-cell lymphomas $(1,3,11,12,18)$. The evaluation of CD10 expression has therefore become an important part of the routine evaluation of B-cell neoplasms.

In contrast, the expression of CD10 by T lymphocytes has received less attention in the literature.
CD10 is expressed by a subset of immature thymocytes and is generally thought to be absent on mature $\mathrm{T}$ cells $(1,2)$. Cutrona and colleagues (19), however, reported that $\mathrm{T}$ cells subjected to apoptotic stimuli in vitro express CD10 and that apoptotic $\mathrm{T}$ cells isolated from HIV-infected lymph nodes are also $\mathrm{CD} 10^{+}$. More recently, $\mathrm{CD} 10^{+} \mathrm{T}$ cells have also been described in two forms of mature T-cell lymphomas. Attygalle et al. (6) demonstrated that $\mathrm{CD} 10^{+} \mathrm{T}$ cells could be identified by paraffin section immunohistochemistry in $90 \%$ of cases of angioimmunoblastic T-cell lymphoma, where they tended to be concentrated near the periphery of germinal centers in cases with residual follicular structures. The $\mathrm{CD} 10^{+} \mathrm{T}$ cells always represented a minority of the $\mathrm{CD}^{+}{ }^{+} \mathrm{T}$ cells present, ranging from $5-30 \%$ of all T cells. Microdissection studies indicated that the $\mathrm{CD} 10^{+}$cells had clonal T-cell receptor rearrangements, whereas the $\mathrm{CD}^{-} 0^{-} \mathrm{T}$ cells were polyclonal. $\mathrm{CD} 10^{+} \mathrm{T}$ cells were reportedly absent by paraffin section immunohistochemistry in 10 cases of other peripheral T-cell lymphomas and in 10 reactive lymph nodes. Similarly, Yuan and colleagues (8) have reported in abstract form that two of three cases of angioimmunoblastic T-cell lymphoma contained $\mathrm{CD} 10^{+} \mathrm{T}$ cells, whereas two other cases of peripheral T-cell lymphoma lacked detectable $\mathrm{CD} 0^{+} \mathrm{T}$ cells. Both groups of investigators reported that the neoplastic $\mathrm{CD} 10^{+} \mathrm{T}$ cells express CD4 and, at least in a subset of the neoplastic cells, BCL-6. Other investigators have reported $\mathrm{CD}_{10}{ }^{+} \mathrm{T}$ cells in two of three cases reported as follicular T-cell lymphoma (20). The relationship of these latter cases to angioimmunoblastic T-cell lymphoma is currently unclear. These findings suggest that the demonstration of CD10 expression by neoplastic $\mathrm{T}$ cells may aid in establishing a diagnosis of specific forms of T-cell lymphoma.

To search for a possible benign counterpart to the neoplastic $\mathrm{T}$ cells of angioimmunoblastic T-cell lymphoma, and to further evaluate the diagnostic significance of identifying populations of $\mathrm{CD}^{+} 0^{+} \mathrm{T}$ cells, we retrospectively examined flow cytometric data and histograms from 64 lymph node or other solid tissue biopsies. We demonstrated discrete populations of $\mathrm{CD} 10^{+} \mathrm{T}$ cells in 5 of 28 cases of reactive lymphoid hyperplasia (18\%), 4 of 17 cases of follicular lymphoma (23\%), and 9 of 19 cases of marginal zone lymphoma (47\%). In four additional prospectively identified cases, definitive coexpression of CD3 and CD10 was identified. The frequency of these cells in other forms of malignant lymphoma not examined in this study remains to be determined. It is unclear whether, in cases lacking distinct populations of $\mathrm{CD}^{+} 0^{+} \mathrm{T}$ cells, such cells are completely absent or are simply present at a level below the limits of detection with routine flow cytometric analysis. We could not identify specific 
morphologic or other phenotypic differences between the cases with and without distinct CD10 ${ }^{+}$ T-cell populations.

Two-color paraffin section immunohistochemistry was then used to identify the location of the $\mathrm{CD}{ }^{+} \mathrm{T}$ cells in select cases. In the absence of a good nuclear T-cell marker, and with the known difficulties in interpreting paraffin section doublesurface immunostains, especially when the cells of interest are infrequent and when negatively staining cells could easily be obscured by numerous surrounding positive cells, a strategy was employed using a nuclear B-cell-specific marker (PAX5) and a CD10 surface stain. The CD10 ${ }^{+} \mathrm{T}$ cells identified by flow cytometry would therefore be seen in the tissue sections as $\mathrm{CD}_{10}{ }^{+} \mathrm{PAX}^{-}$mononuclear cells. Cases of reactive lymphoid hyperplasia contained $\mathrm{CD}_{10}{ }^{+} \mathrm{PAX}^{-}$presumptive $\mathrm{T}$ cells primarily within follicles with scattered cells in the interfollicular areas. The possibility that some of the cells were non-T cells could not be ruled out; however, virtually all B cells are $\mathrm{PAX}^{+}$, the cells did not resemble neutrophils, and the prominent intrafollicular distribution did not suggest a significant NK cell population. As also described by others using paraffin section immunohistochemistry (6), the CD10 staining on $\mathrm{T}$ cells had a more intense, crisp membrane pattern that differed from the less intense, more diffuse membrane and cytoplasmic staining seen in germinal center B cells. The finding of a predominantly intrafollicular location raises the possibility that these cells may have a relationship to the neoplastic cells of angioimmunoblastic T-cell lymphoma or the so-called follicular T-cell lymphoma, as in these settings the malignant $\mathrm{CD} 0^{+} \mathrm{T}$ cells appear to have some association with follicular structures. From these stains, CD10 would appear to be present on only a minority of intrafollicular $\mathrm{T}$ cells. The relationship of these $\mathrm{CD}^{+}{ }^{+} \mathrm{T}$ cells to other intrafollicular T-cell subsets, such as those expressing CD57 or BCL-6, is unclear and merits further investigation.

Interestingly, $\mathrm{CD} 10^{+}$T-cell populations were present in a greater proportion of marginal zone lymphoma cases than in cases of reactive lymphoid hyperplasia or follicular lymphoma. In marginal zone lymphoma cases, the $\mathrm{CD} 10^{+} \mathrm{T}$ cells accounted for $\leq 75.5 \%$ of total $\mathrm{CD}_{10} 0^{+}$cells, possibly due to the presence of follicular colonization and associated loss of benign $\mathrm{CD} 10^{+} \mathrm{B}$-cells. The $\mathrm{CD} 10^{+} \mathrm{T}$ cells in marginal zone lymphoma cases, as with cases of reactive lymphoid hyperplasia and follicular lymphoma, made up only a minority of total $\mathrm{T}$ cells present (range: 4.2-14.4\%). Two color immunostains demonstrated that the $\mathrm{CD}_{10} 0^{+}$presumptive $\mathrm{T}$ cells in these cases were also located primarily within follicular structures in the cases where residual follicles were present.
The physiologic role of CD10 expression by $\mathrm{T}$ cells, if any, is currently unknown. Cutrona et al. (19) reported that apoptotic T cells were $\mathrm{CD} 10^{+}$and showed decreased CD3 expression. The cases in the current study also tended to show somewhat lower CD3 expression in the four cases in which such analysis could be performed, although this decreased intensity was not statistically significant. The previous report found $\mathrm{CD}^{+} 0^{+} \mathrm{T}$ cells in HIVpositive lymph nodes to be present at much greater frequency ( $\leq 70 \%$ of all $\mathrm{T}$ cells) than were identified in the current study. It is unclear whether the large percentage of $\mathrm{CD} 0^{+} \mathrm{T}$ cells observed by these investigators is related primarily to the relative rates of apoptosis, or alternatively, whether a selective expansion of $\mathrm{CD}^{+} 0^{+} \mathrm{T}$ cells may occur in HIVinfected lymph nodes. Additional studies will be required to determine whether $\mathrm{CD}^{+} 0^{+} \mathrm{T}$ cells represent only $\mathrm{T}$ cells undergoing cell death or a stable T-cell subset.

This study demonstrates that benign $\mathrm{CD}^{+} 0^{+} \mathrm{T}$ cells may be found by flow cytometric studies in a variety of settings other than angioimmunoblastic $\mathrm{T}$-cell lymphoma. The lack of $\mathrm{CD} 10^{+} \mathrm{T}$ cells in cases of reactive lymphoid hyperplasia reported by others using paraffin section immunohistochemistry (6) likely reflects the superiority of flow cytometry in identifying small, phenotypically distinct cell populations. Although the $\mathrm{CD}^{+} 0^{+} \mathrm{T}$ cells identified in the current study made up only a small proportion of total cells ( $1-6 \%$ of cells analyzed), this percentage is similar to that found in many cases of angioimmunoblastic T-cell lymphoma (6). Therefore, although the presence of a $\mathrm{CD} 10^{+} \mathrm{T}$-cell population may be characteristic of angioimmunoblastic T-cell lymphoma, establishing a definitive diagnosis requires correlation with all available morphologic and immunophenotypic findings.

\section{Note Added in Proof}

Study of three additional cases shows $>90 \%$ of the CD10+ T-cells are CD $4+$ but $<50 \%$ are CD57+.

Acknowledgment: We are grateful to Kim StanisFuhrer for expert assistance with two-color immunohistochemical stains and to the UPMCPresbyterian flow cytometry laboratory for excellent technical assistance.

\section{REFERENCES}

1. Arber D. CD10: a review. Appl Immunohistochem Mol Morphol 1997;5:125-40.

2. LeBien TW, McCormack RT. The common acute lymphoblastic leukemia antigen (CD10)_emancipation from a functional enigma. Blood 1989;73:625-35. 
3. Almasri NM, Iturraspe JA, Braylan RC. CD10 expression in follicular lymphoma and large cell lymphoma is different from that of reactive lymph node follicles. Arch Pathol Lab Med 1998;122:539-44.

4. Jaffe E, Ralfkiaer E. Angioimmunoblastic T-cell lymphoma. In: Jaffe E, Harris N, Stein H, Vardiman J, editors. Tumours of haematopoietic and lymphoid tissues. Lyon, France: IARC Press; 2001. p. 225-6.

5. Ferry JA. Angioimmunoblastic T-cell lymphoma. Adv Anat Pathol 2002;9:273-9.

6. Attygalle A, Al-Jehani R, Diss TC, Munson P, Liu H, Du MQ, et al. Neoplastic $\mathrm{T}$ cells in angioimmunoblastic T-cell lymphoma express CD10. Blood 2002;99:627-33.

7. Attygalle A, Diss TC, Isaacson PG, Dogan A. CD10 expression in extranodal dissemination of angioimmunoblastic T-cell lymphoma [abstract]. Mod Pathol 2002:964.

8. Yuan C, Vergilio J, Harris N, Bagg A. Angioimmunoblastic T-cell lymphoma. A neoplasm of intrafollicular CD10+, BCL6+, CD4+ memory T cells [abstract]? Mod Pathol 2002:1125.

9. Cook J, Craig F, Swerdlow SH. Bcl-2 expression by multicolor flow cytometric analysis assists in the diagnosis of follicular lymphoma in lymph node and bone marrow. Am J Clin Pathol 2003;119:145-51.

10. Jaffe E, Harris N, Stein H, Vardiman J. Tumours of haematopoietic and lymphoid tissues. Lyon, France: IARC Press; 2001.

11. Chen CC, Raikow RB, Sonmez-Alpan E, Swerdlow SH. Classification of small B-cell lymphoid neoplasms using a paraffin section immunohistochemical panel. Appl Immunohistochem Mol Morphol 2000;8:1-11.
12. King BE, Chen C, Locker J, Kant J, Okuyama K, Falini B, et al. Immunophenotypic and genotypic markers of follicular center cell neoplasia in diffuse large B-cell lymphomas. Mod Pathol 2000;13:1219-31.

13. Brown G, Hogg N, Greaves M. Candidate leukaemia-specific antigen in man. Nature 1975;258:454-6.

14. Trejdosiewicz LK, Malizia G, Oakes J, Losowsky MS, Janossy G. Expression of the common acute lymphoblastic leukaemia antigen (CALLA gp100) in the brush border of normal jejunum and jejunum of patients with coeliac disease. J Clin Pathol 1985;38:1002-6.

15. Metzgar RS, Borowitz MJ, Jones NH, Dowell BL. Distribution of common acute lymphoblastic leukemia antigen in nonhematopoietic tissues. J Exp Med 1981;154:1249-54.

16. Braun MP, Martin PJ, Ledbetter JA, Hansen JA. Granulocytes and cultured human fibroblasts express common acute lymphoblastic leukemia-associated antigens. Blood 1983;61:718-25.

17. Yaziji H, Gown AM. Immunohistochemical analysis of gynecologic tumors. Int J Gynecol Pathol 2001;20:64-78.

18. Dogan A, Bagdi E, Munson P, Isaacson PG. CD10 and BCL-6 expression in paraffin sections of normal lymphoid tissue and B-cell lymphomas. Am J Surg Pathol 2000;24:846-52.

19. Cutrona G, Leanza N, Ulivi M, Melioli G, Burgio VL, Mazzarello G, et al. Expression of $\mathrm{CD} 10$ by human $\mathrm{T}$ cells that undergo apoptosis both in vitro and in vivo. Blood 1999;94: 3067-76.

20. de Leval L, Savilo E, Longtine J, Ferry JA, Harris NL. Peripheral T-cell lymphoma with follicular involvement and a CD4+/ bcl-6+ phenotype. Am J Surg Pathol 2001;25:395-400.

\section{Book Review}

\section{Fox H, Wells, M: Haines and Taylor Obstetrical and Gynaecological Pathology, Fifth Edi- tion, 1626 pp, London, Churchill Living- stone, 2003 (\$450.00).}

Unlike most new editions, the latest edition of Haines and Taylor's Obstetrical and Gynaecological Pathology is actually shorter than the previous edition! Not that this textbook is small; it is still two volumes, 49 chapters, and quite comprehensive. Many of the chapters that were added to the fourth edition have been dropped, such as separate chapters on immunopathology, immunohistochemistry, quantitative pathology, and molecular pathology. Instead, these topics are discussed in the context of specific pathological entities, though there is a short chapter on the application of new techniques at the end. A nice addition is a summary of chapter contents, with page numbers, at the beginning of each chapter.

About a third of the authors are new, bringing a "freshened" look to some chapters. For example, Dr. Paradinas has added substantial insight to the trophoblastic diseases chapter, with new pictures and discussions of newly de- fined entities, such as the epithelioid trophoblastic tumor. The addition of a section on differential diagnosis of lesions containing chorionic villi is also helpful to the practicing pathologist. In another example, Dr. Zaino has brought a simplified look to the chapter on endometrial hyperplasias and carcinoma, with the deletion of the discussion on endometrial metaplasias (metaplasias have been moved to the chapter on an expanded normal endometrium and nonproliferative conditions of the endometrium chapter). The more complex look of tables and graphs that characterize Drs. Kempson and Hendrickson's work is gone.

This text covers more topics than most other textbooks of gynecological pathology, including the pathology of other organs during pregnancy. These topics are rarely touched upon elsewhere and make this text a valuable addition to the pathology library.

\section{I-Tien Yeh \\ University of Texas Health Science Center at San Antonio \\ San Antonio, Texas}

